\title{
Analysis of the microstructural evolution of composite of Tungsten with lignin kraft
}

\author{
SOUZA, A. C. ${ }^{1 *}$; ROSSI, J. L. ${ }^{2}$; FERNANDES, H. B. ${ }^{3}$; GOUVÊA, A. F. G. ${ }^{3}$;
}

1 State University of Mato Grosso do Sul/ Department of Physics - CEPEMAT/UEMS, Dourados, MS, Brazil.

2 Institute of Energy and Nuclear Research, IPEN - CNEN, São Paulo, SP, Brazil.

3 State University of Mato Grosso do Sul/ Department of Forestry Engineering, Aquidauana, MS, Brazil.

*e-mail: armandocirilo@yahoo.com

\begin{abstract}
In materials science and engineering, there is a demand in new materials for radiation shielding in the transport of radiopharmaceuticals used in the diagnosis and therapy of cancer, justifying the interest in developing this work. The obtained lignin kraft and tungsten form the precursors used for metal-organic composite. Tungsten metal has diverse applications in the nuclear sector presents an enormous mechanical strength and an excellent cross section with thermal neutrons. The aim of this study is to analyse the microstructural evolution of metal-organic composite using the kraft lignin and tungsten, using analysis of scanning electron microscopy (SEM), microhardness test and x-ray diffraction (XRD). Microscopic analysis showed the granulometry of the precursors separate and composite morphology, observing the formation of alpha $(\alpha)$ and beta $(\beta)$ phases and absence of oxidation process for different heat treatment temperatures. The spectra of $x$-ray diffraction identified the structures of each phase formed and micro hardness measures showed an increase of mechanical resistance with temperature. The results of the microstructural characterization of metal-organic composite, will contribute in the next steps of attenuation measurements of gamma radiation.
\end{abstract}

Keywords: Tungsten; Composite; Lignin Kraft.

\section{Resumo}

$\mathrm{Na}$ ciência dos materiais e na engenharia, há uma demanda em novos materiais para proteção contra radiação no transporte de radiofármacos utilizados no diagnóstico e terapia do câncer, justificando o interesse em desenvolver este trabalho. A lignina kraft obtida e o tungstênio formam os precursores utilizados para o composto metal-orgânico. O metal de tungstênio tem diversas aplicações no setor nuclear, apresenta uma enorme resistência mecânica e uma excelente seção transversal com neutrons térmicos. O objetivo deste estudo é analisar a evolução microestrutural do composto metal-orgânico utilizando a lignina kraft e tungstênio, utilizando análise de microscopia eletrônica de varredura (SEM), teste de micro dureza e difração de raios $X(X R D)$. A análise microscópica mostrou a granulometria dos precursores separada e morfologia compósita, observando a formação de fases alfa ( $\alpha$ ) e beta $(\beta)$ e ausência de processo de oxidação para diferentes temperaturas de tratamento térmico. Os espectros de difração de raios $X$ identificaram as estruturas de cada fase formada e as medidas de micro dureza mostraram um aumento da resistência mecânica com a temperatura. Os resultados da caracterização microestrutural de compostos metálicos e orgânicos contribuirão nos próximos passos das medidas de atenuação da radiação gama.

Keywords (Palavras chaves): Tungstênio, Compósito, Lignina Kraft.

\section{Introduction}

The study of characterization of microstructural evolution was rendered a composite of tungsten with lignin kraft [1]. Tungsten metal is used in several applications; in the nuclear sector presents good mechanical resistance and an excellent cross section with thermal neutrons [2].

The cellulosic pulp industry presents one of the most significant economic sectors in the world, justifying a 
growing interest for technological development, directed to the refinement of this waste produced after extraction processes of wood fibers [3]. Lignin is obtained in abundance throughout the world as a by-product of wood pulping; becoming object of several, studies in order to increase your value add [4]. One alternative would be to use the extracted lignin eucalyptus wood in the production of aromatic, phenolic adhesives for wood and phenolic resin as a substitute [3, 4].

The objective this study is to analyse the microstructural evolution of metal-organic composite using the tungsten as a matrix metallic with lignin kraft, through analysis of scanning electron microscopy (SEM) with energy dispersive spectrum (EDS) and x-ray diffraction (XRD) $[5,6]$. So that the results can contribute directly to the achievement of a new tungsten composite-lignin [7] and which can be used in attenuation of gamma radiation and possibly in the making of a device for the carriage of radioactive material and radiopharmaceuticals used in hospitals for diagnosis and cancer therapy [8].

\section{Materials and Methods}

Were used metal powder of tungsten and lignin kraft to produce a composite sample. The samples were produced with $95 \%$ wt of tungsten and $5 \%$ wt of lignin kraft. After obtaining of mixtures of tungsten and lignin precursors, with average particle size in the order 13 $\mu \mathrm{m}$, samples were pressed with on a load of 15 tons $/ \mathrm{cm}^{2}$, getting samples with $1.2 \mathrm{~cm}$ diameter and height in order $0.8 \mathrm{~cm}$. Next step, the samples were subjected thermal treatments in three different temperatures $\left(60,70\right.$ and $\left.80^{\circ} \mathrm{C}\right)$, with heating $10^{\circ} \mathrm{C} / \mathrm{min}$, being held in every for 1 hours interval. The analysis of $\mathrm{x}$-ray diffraction (XRD) were performed using $\mathrm{KaCu}$ with $\lambda$ in the order of 1.54056 and $1.54439 \AA$, for identification of phases. The analysis of scanning electron microscopy (SEM) with energy dispersive spectroscopy (EDS) was used for observed of the morphology, homogeneity, size of grain and quantitatively the composition of the samples.

\section{Results and Discussion}

X-ray diffraction (XRD) - The Figure 1, represents the spectrum of refinement of $x$-ray diffraction with the aid of the mineral database and through literary Hanawalt methods query and Fink in the comparison of results with the patterns produced by the Joint Committee for Powder Diffraction System (JCPDS) were obtained the lines of phase decomposition of lignin in order to allow for the identification of hidroxyl and phases composed of potassium, calcium and phosphorus.

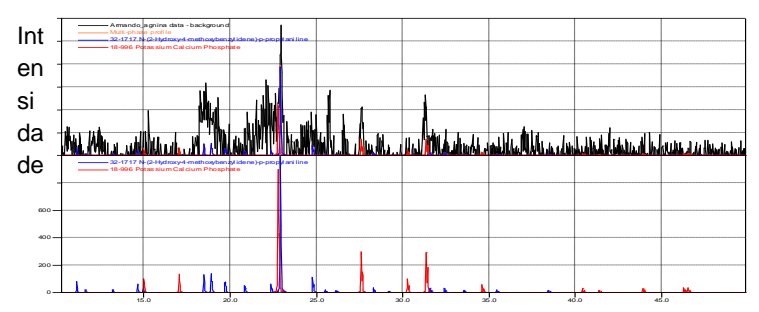

$2 \theta$

Figure 1: Refinement of x-ray diffraction and the identification of phases of the spectrum of the lignin.

Scanning Electron Microscopy (SEM) - The Figure 2, shows the micrographs of the composite precursors. In Figure a) we have the pure kraft lignin powder, in which we can observe a granulometry of less than $100 \mu \mathrm{m}$, in figure b) we have the pure tungsten powder with granulometry in order of $50 \mu \mathrm{m}$, showing excellent homogeneity of the precursors.

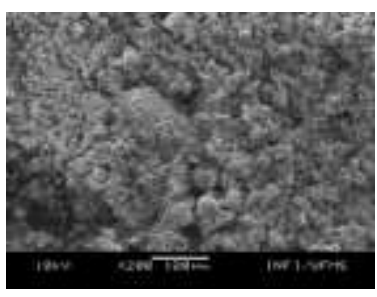

a)

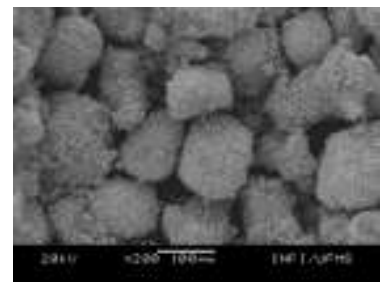

b)
Figure 2: shows the micrographs of the precursors, a) Kraft lignin powder and b) tungsten.

The Figures 3, shows the micrographies of the composite W5\%Lig after the heat treatments at the respective temperatures $60,70,80$ and $90^{\circ} \mathrm{C}$, for 1 hours at each temperature, show a morphological variation on microstructure of samples with, observing a decrease in the composite porosity with increasing temperature, due to the kraft lignin difusion in form adhesiva in the interstices of the tungsten particles, increasing the mechanical resistance and homogeneity of the composite as a whole. 


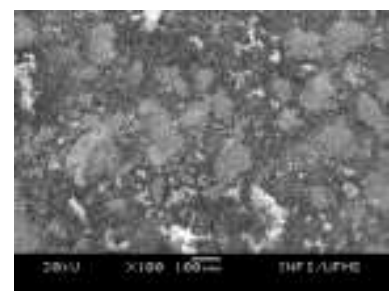

a)

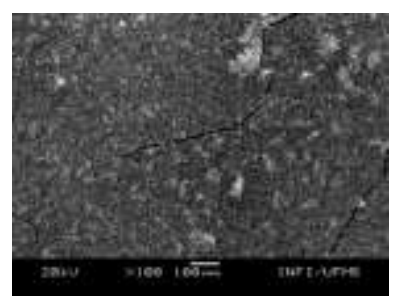

c)

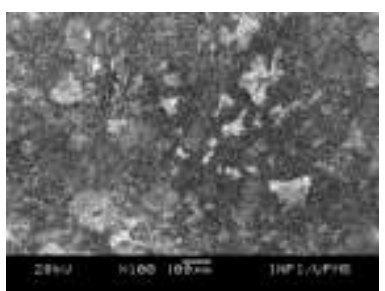

b)

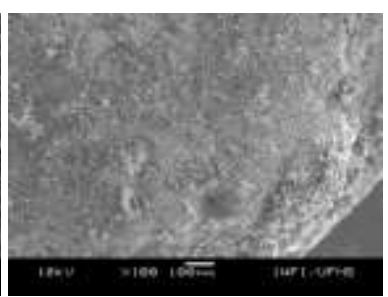

d)
Figure 3: Micrographies of composite W5\%Lig after heat treatment, a) $60^{\circ} \mathrm{C}$, b) $70^{\circ} \mathrm{C}$, c) $80^{\circ} \mathrm{C}$ e d) $90^{\circ} \mathrm{C}$.

Energy dispersive spectrum (EDS) - Figure 4 represents qualitatively the energy dispersive spectrum characteristic of composite W5\%Lig and Table 1 shows the values measured in the sample. The EDS Spectra showed results consistent with the composition of composite, i.e. $95 \%$ by weight of tungsten and $5 \%$ by mass of lignin, where we consider the carbon (C) $29.39 \%$ and tungsten (W) with $50.73 \%$ of the total weight, assigned to mass stoichiometry to form the compound, the atomic oxygen (O) element with $19.88 \%$ is assigned the chemical bonds of the present in kraft lignin hydroxyl obtained from eucalyptus wood that form the phenolic polymer chain and Consequently, the composite structure W5\%Lig.

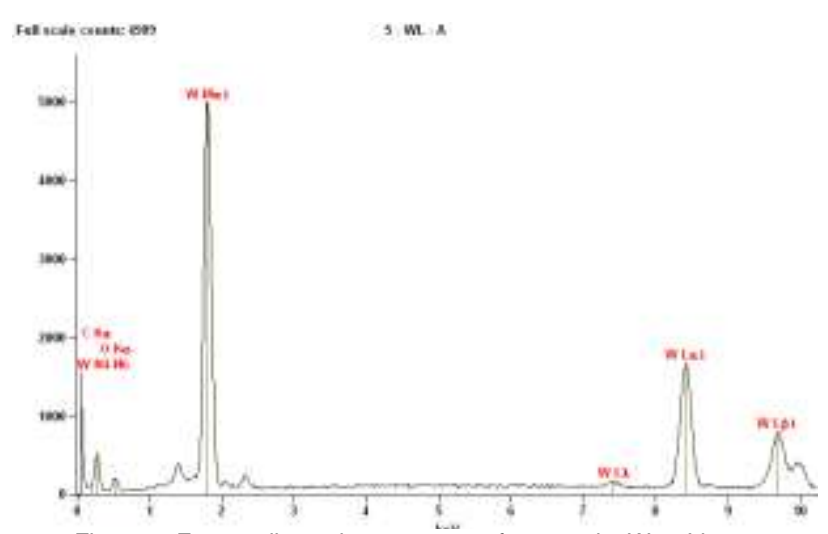

Figure 5: Energy dispersive spectrum of composite W5\%Lig.

Table 1: Quantified values of the composite W5\%Lig.

\begin{tabular}{ccccc}
\hline Element & $\begin{array}{c}\text { Weight } \\
\%\end{array}$ & $\begin{array}{c}\text { Weight } \\
\% \text { Error }\end{array}$ & $\begin{array}{c}\text { Atomic } \\
\%\end{array}$ & $\begin{array}{c}\text { Atomic } \\
\% \text { Error }\end{array}$ \\
C K & 29.39 & $+/-4.04$ & 61.70 & $+/-8.49$ \\
O K & 19.88 & $+/-1.15$ & 31.34 & $+/-1.81$ \\
W M & 50.73 & $+/-0.33$ & 6.96 & $+/-0.04$ \\
Total & 100.00 & & 100.00 & \\
\hline
\end{tabular}

4.

\section{Conclusion}

The results, it was possible to observe the evolution microstructural, the formation of phases, particle size and chemical composition of the composite. Microscopic analysis showed the granulometry of the precursors separate and composite morphology, observing the formation of alpha $(\alpha)$ and beta $(\beta)$ and absence of oxidation process for different heat treatment temperatures. The spectra of $x$-ray diffraction identified the structures of each phase formed and micro hardness measures showed an increase of mechanical resistance with temperature. The results of the microstructural characterization of metal-organic composite, will contribute in the next steps of attenuation measurements of gamma radiation $(\mathrm{Y})$, and can be applied in the manufacture of receptacle used for the carriage of radiopharmaceuticals.

\section{References}

[1] M. ZAKARYAN, et al. Int. Journal of Refractory Metals and Hard Materials 64,176-183, 2017.

[2] CHEN, L. C.; MA, S. H. Jornal of Alloys and Compounds, ELSEVIER, 2017.

[3] FATEMEH, F.; ZHONGSHUN, Y.; MARK, A., CHUNBAO, XU. Industrial Crops and Products 91, 295-301, 2016.

[4] YANQIAO, J.; XIANSU, C.; ZUANBIN, Z. Bioresource Technology 101, 2046-2048, 2010.

[5] WENGE CHEN, et al. Materials Letters 205, 198201, 2017.

[6] KILIC, M. et. al. Powder Melallurgy and Metal Ceramics, 55, 1-2, 2016.

[7] MONDAL, A. et. al. Journal Alloy Compd. , 509, 301310, 2011.

[8] WILLIAM D EHMANN AND DIANE E. VANCE, Radiochemistry and Nuclear Methods of Analysis, John Wiley and Sons, New York, 1991. 